УДК $351 / 354$

\title{
Інтернет-сервіс сплати податків та зборів як елемент електронного уряду України
}

\author{
C.В. НАЙАЮК \\ Акалемія митної служби України, м. Аніпропетровськ, Україна, \\ E-mail: stas.naidiyk@gmail.com
}

\begin{abstract}
Авторське резюме
У статті проаналізовано стан готовності України до впровадження електронного уряду. Розроблено концепцію сервісу сплати податків та зборів, що надасть можливості фізичним та юридичним особам отримувати і сплачувати рахунки на сплату державних податків та зборів за допомогою сучасних дистанційних засобів. Запропоновано перелік критеріїв, яким повинен відповідати даний сервіс. Розроблено схему інформаційних потоків сервісу сплати податків та зборів.

Ключові слова: електронний уряд, інформаційні технології, електронний сервіс, інтернет-сервіс, онлайн-транзакції, податки, збори.

\section{Internet-service of payment of taxes and collections as an element of e-government in Ukraine}

\author{
S.V. NAIDIUK \\ Ukrainian academy of customs, Dnipropetrovsk, Ukraine, \\ E-mail: stas.naidiyk@gmail.com
}

\section{Abstract}

The article analyzes the state of Ukraine to electronic-government. The concept of service taxes and fees is developed and this will provide the possibility for physical and legal persons to receive and pay bills to pay state taxes and fees with a help of modern distance means. It is proposed a list of criteria to which this service must conform. The diagram of information flows service payment of taxes and fees is developed.

The author proposes the concept of service taxes and fees as the element of electronic government in Ukraine which operates in routine $24 / 7 / 365$ and provides a convenient, rapid, distance formation of accounts and their payment with a help of the reverse informing taxpayer to held transaction with a low level of commission while paying taxes and fees due to the banks competition and payment service providers that is involved to implementation of this service, timely receipts to the state budget of Ukraine, reducing time for service taxpayers.

Keywords: electronic government, information technologies, electronic service, internet service, online transaction, taxes, tax collection.

Постановка проблеми. При переході до користування новими, більш високого ступеня розвитку, інформаційно-комунікаційними технологіями, урядові структури, громадськість, бізнес-структури отримують великі переваги, які досягаються завдяки більш досконалому рівню при взаємодіях держави з державою, держави з бізнесом та держави з громадянами.

Бюрократизм і корупція, як головні проблеми державної влади, сьогодні є не тільки питання ефективності сис(c) С.В. Найдюк, 2014 теми адміністративного управління - це бар’єр економічного зростання України, розвитку українського бізнесу, припливу інвестицій на її територію. Важливим моментом, що виступає в якості вагомого аргументу в питанні формування електронного уряду України, є світова тенденція розгляду електронного уряду як реального шляху розвитку демократичних принципів у суспільстві.

Більшість українських підприємств практично всіх галузей економіки застосовують інформаційно-комунікаційні 
технології (далі - IКТ) не тільки для автоматизації виробничих і технологічних процесів, а й для процесів управління. Все ширше розвиваються процеси електронної торгівлі і платежів. Сучасні технології використовуються для організації обміну інформацією в електронному вигляді між організаціями та споживачами, де інтернет виступає як стандартний засіб комунікації. ІКТ активно впроваджуються і в систему державного управління. В даний час вирішено завдання, пов'язані 3 формуванням в органах державної влади сучасної базової інформаційно-комунікаційної інфраструктури. Для досягнення пріоритетних завдань розвитку електронної комунікації задовольняються потреби органів державної влади в комп'ютерній техніці, створюються локальні і територіально розподілені відомчі комп'ютерні мережі, все ширше надається доступ до інтернет-технологій державним службовцям [1]. Однак розвиток державних інформаційних систем, що забезпечують автоматизацію процедур збору, обробки та зберігання відомостей, необхідних для виконання покладених функцій на ці органи поки що знаходиться на стадії становлення. Виклики сучасного суспільства вимагають від держави прискорення цього процесу.

Аналіз досліджень та публікацій. Особливе місце в наукових дослідженнях, увага до яких зростає з кожним роком, займають електронний уряд та інформаційне суспільство і їх взаємодія. Увагу проблемі становлення електронного уряду та електронного (інформаційного) суспільства приділено багатьма сучасними іноземними та українськими дослідниками.

Олександр Прохоров [2] вважає, що стратегія створення електронного уряду базується на таких положеннях:

- децентралізація - передача повноважень у прийнятті рішень на регіональний і місцевий рівні управління з метою зменшення витрат на централізоване прийняття рішень;

- підвищення відповідальності державного сектора за прийняті рішення (створення механізму, що мотивує боротьбу з корупцією);
- поліпшення управління ресурсами, підвищення ефективності використання людських, фінансових та інших ресурсів;

- впровадження елементів ринкових відносин, які повинні знижувати витрати і підвищувати ефективність прийняття рішень;

- використання IКТ для управління всіма видами інформації в державному секторі.

Андреа ді Майо [3] визначав електронний уряд як перетворення внутрішніх i зовнішніх взаємозв'язків у державному секторі за рахунок мережевих операцій і використання інформаційно-комунікаційних технологій для оптимізації надання державних послуг, участі громадян та їх залучення в державне управління.

Павлютенко М.Ю., Сваруп А.А. [4] стверджують, що «електронний уряд» це нова модель державного управління, що з'явилася в результаті перетворення традиційних відносин громадян і влади. Світовий досвід показує, що модель електронного уряду природна і приваблива для тих країн і культур, в яких держава сприймається як обслуговуюча, сервісна структура.

Дубов Д. В., Ожеван М. А., Гнатюк С. Л. [5] дають визначення інформаційного суспільства - це передусім гуманітарна категорія, що описує якісні суспільні трансрормації, зміщення акцентів $з$ виробничої до невиробничої сфер, зміну характеру інформаційних потоків, групових та індивідуальних ідентичностей. Також стверджують, що в коротко- й середньостроковій перспективах на теренах України триватимуть процеси повномасштабної імплементації інтернет-сервісів та відповідних технологій, конвергенції традиційних і розвитку нових медіа-форматів на технологічній платформі інтернет. Уже зараз в Україні стрімко формується масова інтернетаудиторія та специфічне мережеве соціокультурне середовище, що за своїми основними параметрами буде подібне до таких у розвинених країнах.

Враховуючи стрімкий розвиток інтернет-технологій, зручність використання інтернет-послуг та зростаючий попит суспільства на інтернет-послуги (сервіси) в 
державному секторі, впровадження електронного уряду в Україні є досить перспективним вектором дослідження.

Мета дослідження. Автор ставить за мету аналіз можливостей впровадження сервісу сплати податків та зборів як елементу електронного уряду в Україні.

Виклад основного матеріалу. В інформаційному суспільстві, для якого характерно інтенсивний розвиток інформаційно-телекомунікаційної революції, проникнення інформаційних технологій в усі сфери суспільного життя, становлення глобальної інформаційної економіки, електронних видів зайнятості, електронних форм державного і корпоративного управління, формування інфосфери і глобального мережевого середовища людського спілкування, важливе місце і роль відводиться електронному уряду [4].

Уряди більшості розвинених країн світу прекрасно усвідомлюють перспективи використання мережевих та інтернет-технологій у державному управлінні, розробили і реалізують національні концепції інформаційного розвитку. Одні країни перебувають на початковій стадії цього процесу, тільки позначаючи свою присутність у глобальному інтернетпросторі, інші вже переходять до вищої стадії інформатизації державного управління - транзакціях з громадянами та бізнесом.

Залежно від ступеня присутності органів державного управління в мережі інтернет виділяють етапи розвитку інтернетизації уряду .

На початковому етапі урядові сайти містять мінімальну кількість інформації про орган державного управління, а саме: його структуру, функції, завдання, а також відомості про його керівний склад. Другим етапом є розвиток інтерактивних елементів, що передбачає вже можливості завантаження типових форм різних офіційних документів, організація взаємодії через веб-сайт, а далі - здійснення угод (транзакцій) в онлайн-режимі, таких, як оплата податків, реєстраційних i ліцензійних зборів, штрафів, отримання соціальних допомог і т. д. На заключному етапі відбувається повна інтеграція електронних послуг у межах адміністра- тивних кордонів за допомогою створення єдиної точки доступу до консолідованої інформації всіх урядових відомств і повному комплексу електронних послуг у вигляді урядового порталу робота якого здійснюється за принципом «одного вікна» 24 години на добу 7 днів на тиждень 365 днів на рік.

Інтернет-технології, що забезпечують інформаційну взаємодію органів влади 3 населенням та інститутами громадянського суспільства, отримали в сучасній літературі стійке найменування «електронного уряду» (e-Government). Він розглядається як єдиний соціально відповідальний та інформаційно відкритий, 3 постійним зворотним зв'язком інститут. 3 цієї точки зору вся система органів виконавчої влади виступає як єдина сервісна організація, призначена для надання послуг населенню. Діяльність уряду представляється досить відкритою, інформаційно-прозорою i доступною для громадян [6].

Створені інтернет-сайти більшості органів державної влади, де розміщена нормативно-правова, довідкова та новинна інформація, пов'язана 3 їх діяльністю. Проводиться систематична робота по опису функцій і процесів державного управління, аналізу можливостей їх оптимізації та вдосконалення на основі застосування сучасних IКT [1].

Онлайн-транзакції абезпечують надання послуг державних i муніципальних установ через інтернет - оплату комунальних платежів, заповнення податкових декларацій та збір податків, реєстрацію громадських об’єднань, а в перспективі - підприємців без утворення юридичної особи, підприємств малого бізнесу та ін. На цій стадії формується «інформаційна економіка» в результаті постійного інтерактивного функціонування державних порталів. Переваги руху в даному напрямку очевидні, зокрема забезпечення легко-верифікованої, суворої податкової підзвітності шляхом введення уніфікованої системи електронного обліку, підвищення рівня бюджетних надходжень, скорочення масштабів корупції та, відповідно, зростання довіри громадян до інститутів влади [7]. Найбільшо- 
го успіху у використанні інтернет-технологій досягли країни ЄС та Північної Америки, Східної Азії, де уряди хочуть і можуть собі дозволити витрачати чималі кошти на інформатизацію управління державою. Досвід цих країн показав, що при стабільному фінансуванні та ефективному управлінні ця ініціатива здатна в короткі терміни відшкодувати витрачені кошти. При цьому громадяни отримують реальний шанс брати участь в діалозі з владою, впливати на прийняття рішень і висувати власні ініціативи, отримувати детальну інформацію про роботу державних структур і здійснювати контроль за їх діяльністю. Йдеться, зокрема, про такі держави, як Фінляндія, Сінгапур, Швеція, Гонконг, США, Великобританія, Люксембург, Німеччина, Естонія. Досвід цих країн цікавий різноманітністю інтерактивних сервісів для громадян, що надаються органами влади на всіх рівнях - державному, регіональному, рівні місцевого самоврядування.

В створенні електронного уряду України відчутні відхилення в бік надання лише інформаційних послуг: бази даних, довідкової інформації, стрічки новин, у той час як закордонний вектор більшою мірою орієнтований на активне спілкування з громадянами та надання їм різних інтерактивних послуг. Для переходу України в повній мірі активних онлайнтранзакцій з населенням необхідно подолати багато суттєвих перепон. Насамперед це:

- низький рівень інформатизації країни. Відповідно до рейтингу «Тhe Networked Readiness Index 2014», що оцінює готовність держави до інформаційного суспільства і відповідним управлінським структурам, Україна знаходиться на 81 місці серед 148 розглянутих країн [8];

- бідність населення (розвиток людського потенціалу). Відповідно до щорічного звіту $\mathrm{OOH} \mathrm{з} \mathrm{розвитку} \mathrm{людства}$ «Індексу розвитку людського потенціалу 2013» Україна знаходиться на 83 місці серед 187 розглянутих країн [9];

- відсутність інтересу з боку громадян. Значною мірою це говорить і про небажання чиновників змінювати стиль спіл- кування з громадянами. Надаючи можливість участі громадян, лише в якості спостерігачів, не маючи жодних важелів впливу на державне управління. Така позиція добре демонструє відмінність західної політичної культури, де держава розглядається як сервісна організація, що надає послуги населенню, від української, де чиновник не схильний вважати себе служителем суспільству.

Україна, як і інші країни, включена в об'єктивний процес формування і розвитку глобального економічного і політичного простору. Саме тому формування розвинутої інформаційної інфраструктури як головної умови просування до інформаційного суспільства, стає для нашої країни важливим політичним фактором. Тільки так Україна зможе інтегруватися в світовий економічний простір як рівноправний партнер, повною мірою спираючись на конкурентоспроможну високотехнологічну економіку.

Для забезпечення розбудови електронного уряду та як наслідок електронного суспільства в Україні спираючись на Закон України від 09.01.2007 № 537 «Про Основні засади розбудови інформаційного суспільства в Україні на 2007-2015 роки» [10], Закону України від 13.01.2011 № 2939 «Про доступ до публічної інформації» [11] та Розпорядження Кабінету Міністрів України від 13.12.2010 № 2250 «Про схвалення Концепції розвитку електронного урядування в Україні» [12], пропоную Концепцію сервісу зі сплати податків та зборів як використанням сучасних інтернет-технологій.

Сервіс зі сплати податків та зборів повинен забезпечувати:

- можливість надання сучасних i зручних засобів для сплати податків, що дозволятиме фізичним та юридичним особам оплачувати податки дистанційно в режимі $24 / 7 / 365$, без відвідування відділень банківських установ;

- отримання рахунків для сплати податків та зборів, наприклад, плати за землю, податку на нерухомість, податку на доходи фізичних осіб, єдиного податку тощо;

- скорочення термінів збору платежів 
за рахунок надання зручного сервісу i скорочення часу, необхідного фізичним особам для відвідування банків для здійснення платежів;

- єдиний та прозорий механізм підключення комерційних банків та платіжних сервіс-провайдерів, які будуть виступати партнерами по збору платежів;

- низькій рівень комісій при здійсненні онлайн-транзакцій, за рахунок конкуренції банків та платіжних сервіспровайдерів, залучених до реалізації та підтримки сервісу.

Наведу схему інформаційних потоків Концепції сервісу сплата податків та зборів (далі - Сервіс) (рис.1), відповідно до якої буде здійснюватися обмін інформацією щодо платежу між платником, Державною фіскальною службою України (далі - ДФС України), Державним казначейством України, Банками та платіжними сервіс-провайдерами.

Онлайн-транзакції щодо сплати податків та зборів фізичною особою, фізичною особою-підприємцем та юридичною особою (далі - платник), за допомогою Сервісу можливі 3 використанням як електронного цифрового підпису (далі
- ЕЦП), так і за його відсутності та здійснюється за таким алгоритмом (рис.1.):

1) на офіційному веб-порталі ДФС України або на сайті комерційних компаній платник за гіперпосиланням «Сплата податків та зборів» переходить безпосередньо на сайт Сервісу;

2) на відповідній сторінці Сервісу платник вводить власний індивідуальний податковий номер та вибирає вид податку, який хоче сплатити (податок на землю, податок на нерухомість, єдиний податок тощо), та рахунок, на який сплачується обраний вид податку;

3) для сплати рахунку платник вибирає запропонований метод оплати - банківською платіжною карткою НСМЕП, Visa, MasterCard чи інший платіжну систему, що пропонує Сервіс;

4) після обрання платіжної системи платник автоматично потрапляе безпосередньо на її сайт, де вводить інформацію про суму, яку має намір сплатити, а також персональну інформацію (П.І.Б., адреса);

5) у випадку успішної сплати, платник отримує інформаційне підтвердження та електронну квитанцію, 3 можли-

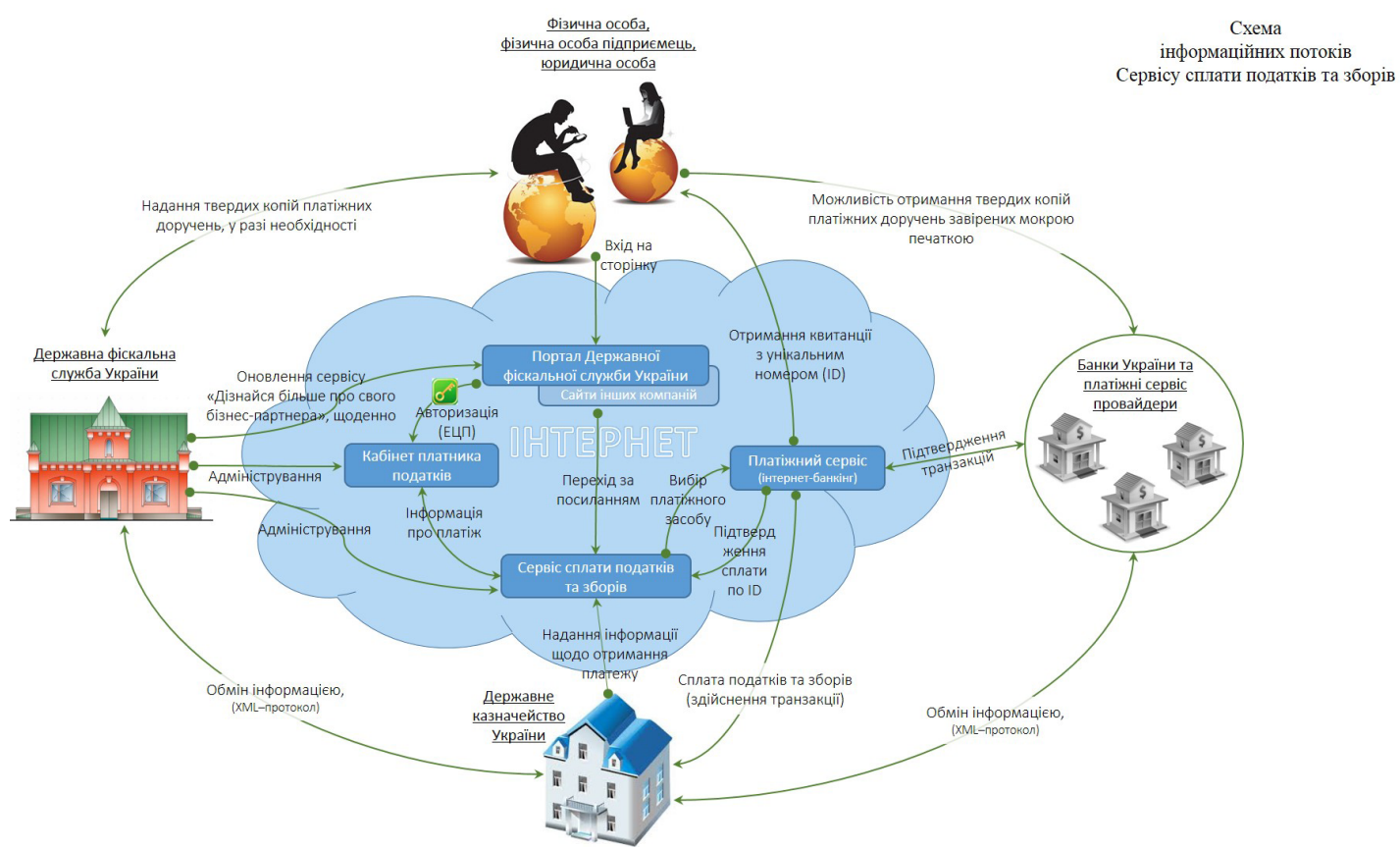

Рис.1. Схема інформаційних потоків сервісу сплати податків та зборів 
вістю її друку, яка містить реквізити визначені відповідними інструкціями НБУ, та унікальний номер (ID) електронної квитанції згенерований засобами платіжної системи.

Для формування платником рахунку на сайті сервісу «Електронний кабінет платника податків», введеного в експлуатацію в Міністерстві доходів і зборів України з 5 грудня 2013 року, платник здійснює авторизацію з допомогою ЕЦП та вибирає платіж 3 переліку доступних йому платежів, який у подальшому завантажується на сайт Сервісу уже в сформованому вигляді. Це полегшує процес створення електронного рахунку та зводить можливість здійснення помилки платником до мінімуму. Так як саме основна більшість завершених онлайнтранзакцій безуспішно, викликана формуванням платежу з помилковими реквізитами. Для підтвердження здійснення онлайн-транзакції щодо сплати податків та зборів банк чи платіжний сервіс-провайдер зобов'язаний надати платнику можливість отримати як електронну, так і паперову з мокрою печаткою (в разі необхідності) квитанцію.

На сайті Сервісу також буде можливо здійснити пошук та підтвердження сплати рахунків, де платник (або третя сторона) матиме можливість перевірити сплату вказаного податку шляхом введення індивідуального податкового номера платника податків та унікального номеру (ID) електронної квитанції та отримати інформацію про те, чи дійсно був такий платіж та які саме платіжні реквізити (МФО, p/p та інше) у ньому вказані. Також Сервіс надаватиме можливість отримати інформацію про отримання платежу Державним Казначейством України.

Технічна та інформаційна взаємодія ДФС України, Державного Казначейства України, банків та платіжних сервіс-провайдерів для забезпечення функціонування даного сервісу буде здійснюватися в режимі офф-лайн при обміні інформацією попередньо розробленим XML-протоколом.

Висновки. Сучасний досвід індустріально розвинених країн показуе, що в рамках діяльності електронного уряду в режимі онлайн для громадян, які мають можливість регулярно використовувати інтернет, стали реально доступними i зручними багато видів державних послуг.

На мою думку, електронний уряд можна визначити як спеціалізовану комплексну структуру взаємодії виконавчої влади з громадянами, громадянським суспільством та бізнес-структурами за допомогою інтерактивних сервісів в мережі інтернет.

Особливу увагу слід приділити тому, щоб відшукати такі форми інтерактивних сервісів, в яких були б рівною мірою зацікавлені і самі органи влади, і громадяни, і бізнес-структури - тільки тоді подібні інтерактивні сервіси матимуть шанс бути успішними та розвиватися без постійного тиску та контролю з боку влади. Оскільки сервіс сплати податків та зборів буде функціонувати в режимі $24 / 7 / 365$, він забезпечуватиме зручне, швидке, дистанційне формування рахунків та їх сплату з можливістю зворотного інформування платника щодо проведеної транзакції, а також низький рівень комісії при сплаті податків та зборів, за рахунок конкуренції банків та платіжних сервіс-провайдерів залучених до реалізації даного сервісу; своєчасне надходження в повній мірі наповнень до державного бюджету України, скорочення часу на обслуговування платників.

Bce це говорить про можливість успішності функціонування сервісу сплати податків та зборів як елемента електронного уряду та електронного суспільства в Україні.

\section{СПИСОК АІТЕРАТУРИ:}

1. Рожков В.Ю. Электронное правительство - перспективы внедрения новых информационно-коммуникационных сервисов / В. Ю. Рожков / / Вестник Московского университета / Серия 10 / Журналистика. - 2010. - № 4. - С. 134-140.

2. Прохоров А. Электронное правительство в цифрах и фактах / А. Прохоров // КомпьютерПресс, - 2006. - №5. - С. 144-150. 
3. Di Maio A. Why Government Is Not A Platform / A. Di Maio // Gartner Blog Network. - 2009. - Access mode: http://blogs.gartner.com/andrea_dimaio/2009/09/08/why-government-isnot-a-platform/

4. Павлютенкова М.Ю. Социально-политические аспекты концепции «Электронное правительство» / М.Ю. Павлютенкова, А.А. Сваруп // Технологии информационного общества

- Интернет и современное общество: труды VII Всероссийской объединенной конференции. Санкт-Петербург, 10-12 ноября 2004 г. - СПб.: Изд-во Филологического ф-та СПбГУ, 2004. - С. 193-195.

5. Дубов Д. В. Інформаційне суспільство в Україні: глобальні виклики та національні можливості / Д.В. Дубов, М.А. Ожеван, С.Л. Гнатюк. - К., НІСД, 2010. - 29 с.

6. Ирхин Ю.В. «Электронное правительство» и общество: мировые реалии и Россия (сравнительный анализ) / Ю.В. Ирхин / Социологические исследования. $-2006 .-$ № 1. - С. 73-82. 7. Демпси Дж. Электронное правительство и его выгоды для широких масс / Дж. Демпси // Государственное управление в переходных экономиках: Ежеквартальное издание программы «Инициатива реформирования местного самоуправления и государственных услуг» / Институт открытого общества. - 2003. - С. 24-27.

8. Глобальний звіт про розвиток інформаційних технологій у 2014 році: 44-й Всесвітній економічний форум у Давосі. - Режим доступу: http://www3.weforum.org/docs/GITR/2014/ GITR OverallRanking_2014.pdf.

9. Малик Халид, Есперсен Эва Доклад о человеческом развитии 2014 / Х. Малик, Э. Есперсен // Программа развития Организации Объединенных Наций (ПРООН) «Обеспечение устойчивого прогресса человечества: уменьшение уязвимости и формирование жизнестойкости». - Токио, 2014. - $28 \mathrm{c.}$

10. Про Основні засади розвитку інформаційного суспільства в Україні на 2007-2015 роки.: Закон України від 09 січня 2007 № 537-V // Відомості Верховної Ради України. - 2007. № 12. - стор. 511. - ст. 102.

11. Про доступ до публічної інформації: Закон України від 31 січня 2011 № 2939-VI // Відомості Верховної Ради України - 2011. - № 32. - стор. 1491. - ст. 314.

12. Про схвалення Концепції розвитку електронного урядування в Україні: Розпорядження від 13 грудня 2010 № 2250-р // Офіційний вісник України. - 2010. - № 97. - стор. 48. - ст. 3443.

\section{REFERENCES:}

1. Rozhkov V.Yu. Elektronnoe pravitelstvo - perspektivyi vnedreniya novyih informatsionnokommunikatsionnyih servisov (E-government - the prospects of introduction of new information and communication services). Vestnik Moskovskogo universiteta / Seriya 10 / Zhurnalistika. 2010. № 4. P. 134-140.

2. Prohorov A. Elektronnoe pravitelstvo v tsifrah i faktah (E-government in facts and figures). KompyuterPress, 2006. №5. P. 144-150.

3. Di Maio A. Why Government Is Not A Platform. Gartner Blog Network. 2009. Access mode: http://blogs.gartner.com/andrea dimaio/2009/09/08/why-government-is-not-a-platform 4. Pavlyutenkova M.Yu. Sotsialno-politicheskie aspektyi kontseptsii «Elektronnoe pravitelstvo» (Socio-political aspects of the concept of «e-government»). Tehnologii informatsionnogo obschestva - Internet i sovremennoe obschestvo: trudyi VII Vserossiyskoy ob'edinennoy konferentsii. Sankt-Peterburg, 10-12 noyabrya 2004 g. SPb.: Izd-vo Filologicheskogo f-ta SPbGU, 2004. P. 193-195.

5. Dubov D. V. Informatsiine suspilstvo v Ukraini: hlobalni vyklyky ta natsionalni mozhlyvosti (The Information Society in Ukraine: global challenges and local opportunities). K., NISD, $2010.29 \mathrm{p}$.

6. Irhin Yu.V. «Elektronnoe pravitelstvo» i obschestvo: mirovyie realii i Rossiya (sravnitelnyiy analiz) («E-government» and society: global reality and Russia (comparative analysis)). Sotsiologicheskie issledovaniya. 2006. № 1. P. 73-82.

7. Dempsi Dzh. Elektronnoe pravitelstvo i ego vyigodyi dlya shirokih mass (E-government and its benefits to the masses). Gosudarstvennoe upravlenie v perehodnyih ekonomikah: Ezhekvartalnoe izdanie programmyi "Initsiativa reformirovaniya mestnogo samoupravleniya $i$ gosudarstvennyih uslug" / Institut otkryitogo obschestva. 2003. P. 24-27.

8. Hlobalnyi zvit pro rozvytok informatsiinykh tekhnolohii u 2014 rotsi: (44-y Vsesvitnii ekonomichnyi forum $u$ Davosi) (Global report on the development of information technology in 2014: (44th World Economic Forum in Davos)). Access mode: http://www3.weforum.org/docs/ GITR/2014/GITR_OverallRanking_2014.pdf. 
9. Malik Halid, Espersen Eva Doklad o chelovecheskom razvitii 2014 (Human Development Report 2014). Programma razvitiya Organizatsii Ob'edinennyih Natsiy (PROON) «Obespechenie ustoychivogo progressa chelovechestva: umenshenie uyazvimosti i formirovanie zhiznestoykosti». Tokio, 2014. $28 \mathrm{p}$.

10. Pro Osnovni zasady rozvytku informatsiinoho suspilstva v Ukraini na 2007-2015 roky.: zakon Ukrainy vid 09 sichnia 2007 № 537-V (On the Basic Information Society Development in Ukraine in 2007-2015 .: Law of Ukraine on January 9, 2007 № 537-V). Vidomosti Verkhounoi Rady Ukrainy. 2007. № 12. p. 511 - P. 102.

11. Pro dostup do publichnoi informatsii: zakon Ukrainy vid 31 sichnia 2011 № 2939-VI (On access to public information: the law of Ukraine on January 31, 2011 № 2939-VI). Vidomosti Verkhounoi Rady Ukrainy - 2011. № 32. p. 1491. - P. 314.

12. Pro skhvalennia Kontseptsii rozvytku elektronnoho uriaduvannia v Ukraini: Rozporiadzhennia vid 13 hrudnia 2010 № 2250-r (On the approval of the concept of e-government in Ukraine: Resolution of 13 December 2010 № 2250-p). Ofitsiinyi visnyk Ukrainy. 2010. № 97. p. 48. - P. 3443.

Найдюк Станіслав Васильович - аспірант Академія митної служби України

Адреса: 49044, м. Дніпропетровськ, вул. Рогальова, 8

E-mail: stas.naidiyk@gmail.com

Naidiuk Stanislav Vasilievich - postgraduate

Ukrainian academy of customs

Address: 8, Rohalov Str., Dnipropetrovsk, 49044

E-mail: stas.naidiyk@gmail.com 